\title{
Dynamism of US Trade and Investment Policy and the Accrual of Economic Benefits for Sub-Saharan Africa Development
}

\author{
Dr Cyrille Mabiata Nzobo \\ nzobosm@hotmail.commabiatac@uni.coventry.ac.uk \\ - $\mathrm{PhD}$ centred on Public Policy and Economics, Coventry University, Department of International \\ Studies and Social Sciences, United Kingdom. \\ - Adjunct Associate Professor, Mazenod University, School of Economics and Management, Kinshasa, \\ Democratic Republic of Congo \\ - Independent Researcher and Consultant
}

\begin{abstract}
US trade and investment policy has consistently sought, although with nuances, to promote American and partners' economic growth and competitiveness by advancing a transparent, open and non-discriminatory trading system, as well as reducing barriers to investment and global trade. This paradigm applied equally to the USSub-Saharan Africa trade and investment relationship. In this context, many have strived to explain with supporting and convincing evidence that US economic interests drive this country trade and investment policy towards Sub-Saharan Africa. However, the current body of literature is silent about the long-run trend of the economic benefits for Sub-Saharan Africa (SSA) development resulting from the dynamism of this US policy. This paper addresses this issue. In this sense, the paper argues that since President Bill Clinton came to power still now, the dynamism of US trade and investment policy towards Sub-Saharan Africa led relentlessly to the accrual of economic benefits deemed capable of paving the way for this region development so much sought after by many. The paper came up with the above claim after analysing a set of interview data on the exercise of US trade and investment policy towards Sub-Saharan Africa (SSA) and by exploring an array of flagship business platforms through which successive US governments engaged for a more re-balancing economic partnership in favour of this Africa's region.
\end{abstract}

Keywords: US trade and investment, accrual of economic benefits, Sub-Saharan Africa development.

DOI: $10.7176 / \mathrm{JESD} / 12-18-08$

Publication date:September $30^{\text {th }} 2021$

\section{Introduction}

The comprehensive history of US trade and investment policy offers a clear picture of various economic forces and factors that have shaped it, considering that the struggle between the winners and losers from the trade has always been fierce (Irwin, 2017). This picture of US trade and investment policy is reflected in the dynamism of this country's economic partnership with Sub-Saharan Africa (SSA), which exhibited a positive evolvement through a set of mechanisms that led to accrued economic benefits for this region. With the African Growth and Opportunity Act (AGOA) turning out to be the centrepiece of the US-Sub-Saharan Africa trade and investment relationship, the dynamism of US trade and investment policy for the development of the last-named partner is perceivable through Millennium Challenge Corporation (MCC), as well as Prosper Africa Initiative and African Global Competitiveness Initiative (US Trade Administration, 2020) ${ }^{\mathrm{ii}}$. US trade and investment policy towards Sub-Saharan Africa also rested on various Trade and Investment Framework Agreements deemed the new approach to the aim of US economic interests in this region, as well as on US-Africa Business Forum and President's Advisory Council on Doing Business in Africa (Card et al., 2011 1iii; Copley, 2018 ${ }^{\mathrm{iv}}$ ). The lack of any study on the link between US trade and investment policy-related platforms and SSA development is the gap within existing research. Hence, investigating and understanding the role of the US trade and investment policy on the development of Sub-Saharan Africa through these business-related platforms is my motivation. Thus, the two missions form the goal of this paper.

The objective of this study is to establish the core mission of the above platforms of US trade and investment policy towards Sub-Saharan Africa regarding their ability or propensity of bolstering this region development by 
changing the balance of economic benefits between both partners. In line with this study objective, an analysis of various trade and investment mechanisms in favour of Sub-Sahara African countries was required, namely, the adjustment of customers barriers, the reverse of investment rules, and the granting of business facilities. US trade and investment policy towards Sub-Saharan Africa is part of enduring duties of the US Department of Commerce, which fosters innovation by setting standards and conducting foundational research, provides US companies and entrepreneurs with invaluable tools through programs, helps negotiate bilateral trade agreements and ensures fair trade with foreign partners (US Department of Commerce) ${ }^{\mathrm{v}}$. The study is not concerned with assessing by any means the impact of the US trade and investment policy platforms referred to above on the development of this region. Nor does it intend to measure any correlation between these platforms and SubSaharan Africa development through economic indicators. These two approaches above are not the missions of this study, which instead focuses on proving, based on data collected and analysed, to what extent these US trade and investment platforms seek to curb underdevelopment settings in Sub-Saharan Africa by offering more trade and investment-related benefits to this part of the Africa continent.

\section{Methodology}

This study rests on the empirical approach because it attempts to gain knowledge by conducting analyses relying upon real-world data. Lasswell $(2002: 286)^{\mathrm{vi}}$ valued the empiricism as he argued that it is ideal to understand policy-makers actions because it reckons on undisputed facts as the foundation of knowledge. Indeed, the approach of this study implies analysing data related to the US trade and investment policy towards Sub-Saharan Africa and then drawing conclusions from these data. The study met then Creswell's (2009, p. 2) ${ }^{\mathrm{vii}}$ aim of developing an objective narrative and language to explain political reality. The central aim of this paper as explained above suited an empirical approach to the study undertaken. About data collection, this study relied upon document review and interviews. Document review consisted of the examination of existing records on the subject. Scott (2006) viii explained that document review implies scrutinising texts as source materials: governmental and other publications. This approach unveiled the official version of US trade and investment policy towards Sub-Saharan Africa not otherwise disclosed. For an all-inclusive review of US official documents, this study took into account the traditional influence of makers and implementers of US politics. Thus, to identify US government documents, an orderly attention was paid to political institutions where official debates on US policy take place; i.e. US Congress, House of Representatives and Senate. The same attention was given to entities where decisions are made; this is to say US government cabinets, as well as to where decisions are implemented, namely US executive and regulatory agencies.

This study was also informed by semi-structured interviews. Due to Covid-19 related travel restrictions during the data collection, interviews were undertaken by Skype, Zoom, MS Teams and E-mails. Alvesson (2002, p. 108-109) ${ }^{\mathrm{ix}}$ indicated that semi-structured interviews unveil the inner world, which includes intentions and ideas experienced by interviewees. Hence, semi-structured interviews enabled respondents to answer questions while confirming the information available. The nature of this study, combined with the profile of respondents, urged the use of open-ended questions. Roberts et al. $\left(2014\right.$, p. 2) ${ }^{\mathrm{x}}$ affirmed that an open-ended question allows respondents to spark eloquence rather than indifference. It does not cue them to back a particular view. Openended questions are constructive as they enable respondents to perform with great spontaneity. Oppenheim $(2001)^{\mathrm{xi}}$ argued that an open-ended question is advisable for analysis relying upon educated respondents since it gives them reasonable freedom, which enables them to answer questions in a way that suits their interpretations. Thus, open-ended questions allow respondents to answer with limited freedom, and so they answer orderly.

Regarding the data analysis technique, this study relied on the triangulation of data and content analysis. Yeasmin and Rahman (2012) $)^{\mathrm{xii}}$ backed the triangulation for validity and verification. In the context of this study, it allowed crosschecking data from US public records against the views of US officials and other non-state actors. The reason is that US official data alone could not shed light on the subject under scrutiny. Pelto (2017, p. 241) ${ }^{\text {xiii }}$ advised the triangulation because it helps assess the trustworthiness of data-gathering methods. Therefore, engaging with multiple sources led to a better understanding. The triangulation reduced the weight given to a single data source and, thus, it enables complementary. This study also relied on 'content analysis' seen as the analysis of actors' standpoints expressed in the political context. Hsieh and Shannon (2005, p. 1277) ${ }^{\mathrm{xiv}}$ argued that content analysis implies scrutinising key words or phrases, followed by their interpretation. Content analysis was of paramount relevance for this study for facilitating the identification of the shift of economic interests for Sub-Saharan Africa through the rhetoric of the US trade and investment policy towards this region as emerging from all sources of data. Content analysis is based on the recurring appearance of words in the text and enables the understanding of data (Yang et al., 2011) ${ }^{\mathrm{xv}}$. It implied then going over the transcripts of data collected and infer based upon the patterns of standpoints appearing from this exploration. 


\section{The roots of US trade and investment policy for Sub-Saharan Africa development}

The first signs of the shift of US trade and investment policy in favour of Sub-Saharan Africa economic benefits go back from President Clinton's era. On this note, US Vice-president Albert Gore revealed to the 1994 White House Conference on Africa that gathered high-ranking businesspersons and US officials involved in African affairs that he pledged for US policy actions for Sub-Saharan Africa to achieve prosperity through trade and investment the US has eluded for so long (White House) ${ }^{\mathrm{xvi}}$. A point agreed to by George Moose, US Assistant Secretary of State for African affairs, when he stated at the Trade and Investment Conference on Africa in San Francisco on 4 April 1996, that the US trade and investment policy towards Africa should now enable this continent to build its economy for its development (US Department of State, 1996) ${ }^{\mathrm{xvii}}$. Dagne $\left(1998\right.$, p. 1) ${ }^{\mathrm{xviii}}$ unveiled that beginning in 1994, the US interest in investment and trade issues related to Africa began to increase, reflecting concerns over the impact of the Uruguay Round Agreements Act on Africa, as it aligned this continent exports to the US with the World Trade Organisation prescriptions. This rhetoric took shape very quickly by means of policy instruments through the US legislative activism. Indeed, as the previous Generalized System of Preferences (GSP) program excluded petroleum products deemed the largest merchandise exports from Africa, US Congress (1998) ${ }^{\mathrm{xix}}$ tried to reverse this trend of US trade policy towards this continent with the passage of the Trade and Tariff Act of 1998. Section 103 of this Act authorised the reduction of tariff and nontariff barriers and other obstacles to all articles from Sub-Saharan Africa (Ibid). A former Country Director of the US Agency for International Development observed that it also permitted the expansion of the US aid to Sub-Saharan Africa's integration, the negotiation of reciprocal and mutually beneficial trade agreements, and the possibility of establishing more free trade areas that could serve the interests of this region ${ }^{\mathrm{xx}}$. Thus, the US approach to improving economic interests for Sub-Saharan Africa through export-import terms and trade agreements meant to project the development of this region.

The above suggests that the legislative branch authorised a new investment and trade policy towards SubSaharan Africa, which was designed to encourage increased trade for this region's economic development. Title I of Trade and Tariff Act of 1998 unveils that as Sub-Sahara African countries exports to the US accounted only for 6.9 per cent in 1997, the US established a new program of trade preferences for these countries to encourage trade and investment in one of the poorest regions in the world (US House of Representatives, 1998) ${ }^{\mathrm{xxi}}$. An Executive Director of the US Office for International trade concurred with the above data and explained that it was in mutual interests of the US and Sub-Saharan Africa to foster sustainable economic growth of the lastnamed region, thereby its development because this region had the economic potential of enduring significance to the US ${ }^{\text {xxii }}$. In this way, Sub-Saharan African countries were granted a competitive edge through unilateral duty-free exports of their products to the US rather than reciprocity trade preference. Hence, the US trade and investment policy approach aligned with the vision for this region's development. President Bill Clinton trade policy towards Sub-Saharan Africa culminated with the inception of the African Growth and Opportunity Act (AGOA) of 2000 that provided a framework for US-Sub-Saharan Africa cooperation on economic issues centred on eliminating duties on nearly everything eligible African countries exports to the US (US Trade Representative, 2009) ${ }^{x x i i i}$. The economic benefits brought by AGOA added to the ones already in place following the enactment of the Trade and Tariff Act of 1998. Thompson (2004, p. 457) $)^{\text {xxiv }}$ explained that no African Embassy in Washington, D.C. opposed the US trade and investment policy because at last, the US would reduce trade barriers and allow their access to the vast American economy. Thus, this US new business policy shows that it would serve Sub-Saharan Africa economic interests, especially when the World Trade Organisation began to derail (Ibid). Through this new momentum to the US trade and investment policy towards Sub-Saharan Africa, the US was prone to forge a new partnership characterised by the re-balance of economic benefits in favour of this Africa's region based on the needs for its economic growth and development. As indicated by Table 1 below, AGOA, effective in January 2001, has substantially increased the volume of US imports from Sub-Saharan Africa. 
Table 6: Fastest-Growing US Imports from SSA under GSP and AGOA

\begin{tabular}{|l|r|r|r|r|}
\hline \multicolumn{1}{|c|}{ Imports Category } & $\begin{array}{c}\text { GSP } \\
\text { Jan-Jun 2001 } \\
\text { (Thousands US } \\
\text { dollars) }\end{array}$ & $\begin{array}{c}\text { AGOA } \\
\text { Jan-Jun 2001 } \\
\text { (Thousands US } \\
\text { dollars) }\end{array}$ & $\begin{array}{c}\text { Total } \\
\text { Jan-Jun 2001 } \\
\text { (Thousands US } \\
\text { dollars) }\end{array}$ & $\begin{array}{c}\text { Increase } \\
\text { in \% due } \\
\text { to AGOA }\end{array}$ \\
\hline Textiles and apparel & 1,948 & 46,089 & 48,037 & $95,9 \%$ \\
\hline Energy Products & $1,599,169$ & $2,832,567$ & $4,431,736$ & $63,9 \%$ \\
\hline Minerals and metals & 135,493 & 33,991 & 169,484 & $20,1 \%$ \\
\hline Agriculture products & 49,307 & 11,646 & 60,953 & $19,1 \%$ \\
\hline Chemicals products & 61,749 & 715 & 62,464 & $1,1 \%$ \\
\hline
\end{tabular}

Source: US International Trade Commission, Second Annual Report December 2001, Page 20

Without going into much detail, data in Table 1 confirm the general increase of US imports resulting from the implementation of AGOA, which authorised preferential treatment, provided duty-free and implemented quotafree treatment for products consigned from Sub-Sahara African countries. President Bill Clinton confirmed this trade policy at the National Summit on Africa on $17^{\text {th }}$ February 2000, at the Washington Convention Centre (White House 2000:276-277) ${ }^{\mathrm{xx}}$. Referring this time to the Overseas Private Investment Corporation in Africa, he explained that the US trade with Africa must not be a race to the bottom (Ibid). It should equally support in the US and Africa many business projects and the creation of jobs than it was the case in the past while talking about harsh working conditions, child labour, future growth and efficient financial sector (Ibid). The underlined idea behind this approach is that the Clinton's Administration made the case that Sub-Saharan Africa turned out to be crucial for the US from both economic and humanitarian perspectives. Schraeder (1998) ${ }^{\text {xxvi }}$ explained that President Bill Clinton administration's emphasis on Sub-Saharan Africa development through bilateral trade was based on the need for a new policy of promoting a new form of business as the preferred economic component of the US foreign policy toward Africa. It was also meant to distinguish his approach from that of the Cold War, especially of his Republican predecessors Ibid). This was both liberal and social business policy and fitted into the context of President Clinton's doctrine of enlargement whose business and economic aspects advocated free trade, fair competition, barriers elimination as well as development for partners, while the US economy would remain as the leading (Clinton Presidential Library and Museum 2000) ${ }^{\mathrm{xxvii}}$. Therefore, this doctrine had also to find its own reason and relevance in the context of the US trade and investment policy towards Sub-Saharan Africa.

Soon after he arrived in office, President George W. Bush's administration took advantage of trade and investment policy instruments available, namely, the Africa Growth and Opportunity Act (AGOA), to further US business policy for Sub-Sahara Africa development. Initiated and passed into law at the end of President Clinton era, in the main, AGOA aims to expand US trade and investment with Sub-Saharan Africa with a view of stimulating this region economic growth, encouraging their mutual integration and facilitating the continent integration into the global economy (US Congress, 1999) ${ }^{\mathrm{xxviii}}$. Zappile (2011) ${ }^{\mathrm{xxix}}$ contended that looking back over the years, as Sub-Saharan Africa exports to the US have doubled to reach $\$ 47$ billion in 2009, AGOA has achieved results and lived up to hopes of a decade, despite the uncertainty about the expiration of preferences, the limited ability of African countries to suitably exploit preferences and the erosion of preferential margins. The approach above was embedded in the US-Common Market for Eastern and Southern Africa (COMESA) Trade and Investment Framework Agreement (TIFA) signed on 29 October 2001. US Trade Representative $(2010)^{\mathrm{xxx}}$ unveiled that this framework agreement recognised the essential role of both partners' private investments and non-tariff barriers in furthering growth, creating jobs, expanding trade, as well as in enhancing economic development and thereby recognising the importance for the economic prosperity of Africa. As also sustained by a Director in the US Bureau of Trade Representative, when given such great attention to SubSaharan Africa development through trade and investment agreements, the US promoted a broader economic policy considering that it has become impossible to separate this region development from the need of the US to deal with businesses in Africa ${ }^{\mathrm{xxx}}$. It was then the sense of US officials that robust economic growth rates in SubSaharan Africa turned out to be crucial for its development. Hence, one of the ways to achieve this goal was to increase the engagement of US investment, considering its beneficial participation in the progress of this region as illustrated by Table 2 . 
Table 7: US Investment in Sub-Saharan Africa (2000-2008) Billions of US dollars

\begin{tabular}{|l|r|r|r|r|r|r|r|r|c|}
\hline $\mathbf{2 0 0 0}$ & $\mathbf{2 0 0 1}$ & $\mathbf{2 0 0 2}$ & $\mathbf{2 0 0 3}$ & $\mathbf{2 0 0 4}$ & $\mathbf{2 0 0 5}$ & $\mathbf{2 0 0 6}$ & $\mathbf{2 0 0 7}$ & $\mathbf{2 0 0 8}$ & $\begin{array}{c}\text { Growth } \\
\text { Rate }\end{array}$ \\
\hline 7.2 & 9.0 & 9.5 & 11.8 & 11.9 & 11.8 & 15.3 & 18.4 & 21.3 & $195.8 \%$ \\
\hline
\end{tabular}

Source: US Trade Representative, 2020 Biennale Report on the Implementation of the African Growth and Opportunity Act, Page 89

What stands out in Table 2 is the continual growth of US investment between 2000 and 2008, with an accumulated rate of $195.8 \%$. This dynamism of US trade and investment policy enhancing economic benefits for the sake of Sub-Saharan Africa development also applied following the inception of the Millennium Challenge Account authorised by Congress then by President George W. Bush in February 2004. In its trade and investment aspects, MCA makes substantial new financial resources available to developing regions like SubSaharan Africa in order to help them move towards more open markets under which small businesses run without the gauntlets of bureaucracy and bribery and so to empower them to promote economic growth and fight poverty (White House, 2004) ${ }^{\mathrm{xxxii}}$. This is compounded by African Global Competitiveness Initiative (AGCI) with a 5-year funding target of US dollar 200 million as announced by President George W. Bush on 7 June

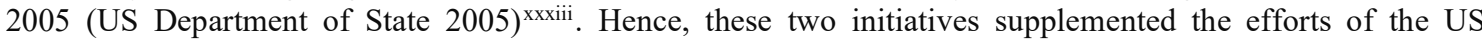
government already in force under AGOA. Indeed, MCA and AGCI advocated the expansion of intra-African trade and the development of the private sector, the diversification of exports, the reduction of transports costs of African commodities, and the improvement of Sub-Sahara African countries capacity to meet international quality standards and US requirements always for this region's development (Ibid). The above dynamic approach also fitted into the US-Easter African Community Trade and Investment Framework Agreement signed on 16 July 2008. This framework agreement was designed in a way that helps Eastern African countries through the cooperation with the US, strengthen their economy and expand trade for their development, and benefit from reduced non-tariff trade barriers that facilitate access to the US markets (US Trade Representative, 2012, p. $2)^{\mathrm{xxxiv}}$. On this note, Yannaca-Small $(2010)^{\mathrm{xxx}}$ explained that the adoption of the US policy for investment and trade for Sub-Saharan Africa has long been under reconsideration in Congress and inexorably led US officials to improve the traditional support of imports from this region. All these platforms aimed to expand the trade and investment capacity building endeavours already underway with Sub-Saharan African countries through previous trade initiatives while allowing their economies to integrate the US and world markets for the continent's overall development. Data presented in Table 3 below are proving to be evidence of this US trade policy under AGOA.

Table 8: Fastest-Growing US Imports from SSA under AGOA during 2001-2008

\begin{tabular}{|l|r|r|r|r|r|}
\hline \multicolumn{1}{|c|}{ Products } & $\begin{array}{c}\text { Year 2001 } \\
\text { Million US\$ }\end{array}$ & $\begin{array}{c}\text { Year 2005 } \\
\text { Million US\$ }\end{array}$ & $\begin{array}{c}\text { Year 2008 } \\
\text { Million US\$ }\end{array}$ & $\begin{array}{c}\text { Absolute } \\
\text { Change } \\
\text { 2001-2008 }\end{array}$ & $\begin{array}{c}\text { Growth } \\
\text { Rate } \\
\text { 2001-2008 }\end{array}$ \\
\hline Chemicals products & 3.8 & 44.7 & 78.0 & 74.2 & $1952.6 \%$ \\
\hline Petroleum products & 278.9 & $1,625.8$ & $1,550.4$ & $1,271.5$ & $455.8 \%$ \\
\hline Minerals and metals & 91.2 & 73.6 & 370.3 & 279.1 & $306.0 \%$ \\
\hline Textiles and apparel & 355.9 & $1,419.0$ & $1,136.9$ & 781.0 & $219.4 \%$ \\
\hline Agriculture products & 59.0 & 151.7 & 162.1 & 103.1 & $174.7 \%$ \\
\hline
\end{tabular}

Source: US International Trade Commission, Publication Number 4461, Pages 45-79

What is striking in Table 3 is the phenomenal growth of US imports from Sub-Saharan Africa under AGOA in terms of both absolute change and percentage between 2001 and 2008. This trade policy was part of President George W. Bush's economic doctrine of 'trade adjustment', which is that the US government had to push for free trade with developing partners while negotiating protectionist measures with them (White House 2007) ${ }^{\mathrm{xxxvi}}$. That is because although it is taken for granted that the net benefits of trade are well-known, jobs in weak partner countries, like Africa, are threatened by international competition (Ibid). About this doctrine, President George W. Bush explained on 18 March 2008 at the Blount Island Marine Terminal in Jacksonville that trade and investment for African countries allow guarantees to foster permanent duty-free access for both partners' products (George W. Bush Presidential Library and Museum 2008) ${ }^{\text {xxxvii }}$. A Director of the US Government Accountability Office corroborated the above evidence and added that President Bush approach intended to lead 
to jobs creation during times of economic uncertainty when consumer spending and investment slow down ${ }^{\mathrm{xxxviii}}$. The above indicates that the US government favoured free trade and negotiates protectionist measures for its investments in Sub-Saharan Africa, considering that their net benefits turn out to be enormous, notably in the context when uncontrolled competition among partners threatens jobs and development in this region. Vandevelde (2009:1) ${ }^{\mathrm{xxx}}$ ascertained that the then-US government inaugurated these investment and trade treaties with the principal purpose of protecting equally US and Sub-Saharan Africa development, rather than the old rhetoric that urged boosting primarily US trade and investment in foreign countries. US Treasury Secretary Henry Paulson underscored the above view on 16 November 2007 before the US-Africa Business Summit on Change and Progress in Africa's business (US Department of the Treasury, 2007). He explained that due to limited financial and trade reform in Sub-Saharan Africa, the US should strengthen trade and private sector primarily in this section of the Africa continent because this could lead to its development (Ibid) ${ }^{\mathrm{xl}}$. The above suggests that here again, the way forward of fostering Sub-Saharan Africa development rested on drawing on multiple trade and investment mechanisms the US kept putting in place like the above two frameworks.

The US government trade policy towards Sub-Saharan Africa in president Obama's era also aligned with the prescriptions of the development of this region. On this note, David Shark, the then-US Representative to the World Trade Organisation, unveiled the US government standpoint that Sub-Saharan Africa countries need a US business and trade policy that enables access for their products and supplies to the US for this region development (US Representative to the World Trade Organisation 2010) ${ }^{\mathrm{xli}}$. The signing of the Trade Preferences Extension Act of 2015 into law by President Barack Obama on 29 June 2015 boosted US trade policy towards Sub-Saharan Africa substantially (White House, 2015) ${ }^{\text {xlii }}$. Thus, the economic benefits for Sub-Saharan Africa accrued again with the passage of the above Act. Indeed, convinced that AGOA enhanced trade, investment and development throughout Africa, it was extended to designate cotton as eligible article for preferential treatment only for Sub-Saharan Africa seen as the least-developed region and a set travel articles for duty-free treatment

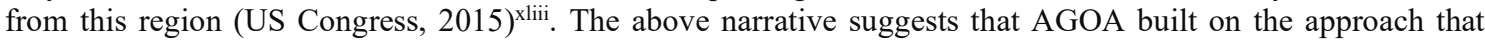
advocated increasing the broad range of products whose preferential access was granted. Thus, the rationale behind this platform is that these preferential advantages could pave the way for the quick integration of SubSaharan Africa countries into the global trading system, thereby furthering their development. Jones (2017, p. $4)^{x l i v}$ argued that the dynamism of this US trade policy proposes a public diplomacy strategy aiming at expanding trade deals that could provide Sub-Saharan Africa with the development, infrastructure and wealth, thereby reducing the need for as much foreign aid. A US Congressional Research Service Officer explained that it also eliminated trade and customs barriers, restrictions on investment, high tariffs and forced localisations, which undermine job creations and opportunities for workers, farmers and other businesses in Sub-Saharan Africa ${ }^{\text {xlv }}$. Hence, for US officials, the elimination of barriers could favour economic benefits for Sub-Saharan Africa, namely US imports from this region, as evidenced by Table 4 below.

Table 9: Fastest-Growing US Imports from SSA under AGOA during 2010-2016

\begin{tabular}{|c|c|c|c|c|c|c|}
\hline Products & $\begin{array}{c}\text { Year } 2010 \\
\text { Million USS }\end{array}$ & $\begin{array}{c}\text { Year } 2012 \\
\text { Million } \\
\text { USS }\end{array}$ & $\begin{array}{c}\text { Year } 2014 \\
\text { Million US\$ }\end{array}$ & $\begin{array}{c}\text { Year } 2016 \\
\text { Million USS }\end{array}$ & $\begin{array}{c}\text { Absolute } \\
\text { Change } \\
\text { 2010-2016 }\end{array}$ & $\begin{array}{c}\text { Growth } \\
\text { Rate } \\
\text { 2010-2016 } \\
\end{array}$ \\
\hline Cooper & 9,7 & 7,9 & 111.2 & 114.3 & 104.6 & $50.9 \%$ \\
\hline Edible nuts & 88 & 115 & 153 & 167 & 79 & $11.3 \%$ \\
\hline Apparel & 795 & 871 & 1.028 & 1.036 & 241 & $4.5 \%$ \\
\hline Coffee and tea & 206 & 254 & 263 & 264 & 58 & $4.2 \%$ \\
\hline Metals and Chemicals & 108 & 104 & 189 & 133 & 25 & $3.5 \%$ \\
\hline
\end{tabular}

Source: US International Trade Commission, Publication Number 4780, Pages 130-167

What can be clearly seen in Table 4 is the general pattern of the US imports from Sub-Saharan Africa, which demonstrated consistent growth for a diversity of products from the countries in this region under AGOA. The underlying trade and investment policy kept consolidating in President Barack Obama's era, notably with President's Advisory Council on Doing Business in Africa, which promotes broad-based economic growth in Africa by encouraging US companies to trade and invest with this continent (White House, 2014) ${ }^{\mathrm{xlvi}}$. President Barack Obama upheld the policy above at the 2014 US-Africa summit attended by US investors of all kinds to promote a partnership with Africa and invest in projects of mutual interests in agriculture, mining, oil and service industries (The American Presidency Project 2017) ${ }^{\mathrm{xlvii}}$. This trade policy concurred partly with President Barack 
Obama's economic doctrine termed 'partnership' and described as moderated liberal by Ashbee and Dumbrell $(2017: 139-140)^{x l v i i i}$ in President Barack Obama's biography. This doctrine rested upon entrepreneurial freedom characterised by open markets, private property rights, as well as free trade for all the partners, notably those in economic needs like Africa (Ibid). President Barack Obama elaborated on his economic doctrine on 4 June 2009 in Cairo, Egypt, as he explained that during his tenure, the US government would build a new corps of global business volunteers i.e. in Africa, in order to work with counterparts to deepen economic ties between business leaders for development (Barack Obama Presidential Library 2017) ${ }^{\text {xlix }}$. He argued, "Considering states interdependence, the US would interact with other countries as 'an equal partner' rather than as the 'exceptional economic power' that many before me had embraced" (Ibid). In other terms, this doctrine suggests that due to economic globalisation, any country, regardless of its economic size, that would attempt to use business opportunities only for its benefits over others, mostly to the detriment of weak states or otherwise developing countries, like Sub-Saharan Africa countries, would not succeed.

This idea has been relayed by US Congressional Research Service (2019), which indicated that the expectation over the US promoting trade with Sub-Saharan Africa is to achieve US national economic-related interests while also putting forward the products from this region. The above alludes that the US seeks to expand markets for both Sub-Saharan African and American investments, exports and imports, rather than bolstering solely American trade. Hendrickson (2014, p. 4) ${ }^{1}$ explained that since Sub-Saharan Africa countries struggled to attract global capital to diversify their economies, this US trade policy was tailored for this region perceived to be the poorest and unreceptive to foreign investments, and thus the most worthy of US government efforts to change this status were within the context of development assistance. Hence, boosting Sub-Saharan Africa partners' economic progress through bilateral trade appears to be a springboard for this region's economic interests in an emerging market where US peer competitors, namely, EU countries and China, keep increasing their economic grip. The approach above was also reflected in the US-Economic Community of West African Countries Trade and Investment Framework Agreement signed on 5 August 2014. Essentially, in addition to reducing tariff barriers that restrained Sub-Saharan Africa products access to the US, this framework allows African countries of this part of the continent to identify specific trade and investment matters and work to remove impediments from the US side, which undermine their economic development (US Trade Representative, 2014, p.3) ${ }^{\mathrm{li}}$. Thereupon, the World Bank (2006:19) lii indicated that while US aid for trade in Sub-Saharan Africa countries played an important role in supporting domestic reforms, it also improved this region's capabilities to trade and investment, and then filled the gaps that impinged on the capacity to trade with the US. This approach is corroborated by data in Table 5 below.

Table 10: US Investment in Sub-Sahara Africa (2009-2015) Billions of US dollars

\begin{tabular}{|c|r|r|r|r|r|r|c|}
\hline $\mathbf{2 0 0 9}$ & $\mathbf{2 0 1 0}$ & $\mathbf{2 0 1 1}$ & $\mathbf{2 0 1 2}$ & $\mathbf{2 0 1 3}$ & $\mathbf{2 0 1 4}$ & $\mathbf{2 0 1 5}$ & $\begin{array}{c}\text { Growth } \\
\text { Rate }\end{array}$ \\
\hline 25.7 & 33.2 & 33.0 & 29.7 & 34.1 & 37.5 & 29.4 & $14 \%$ \\
\hline
\end{tabular}

Source: US Trade Representative, 2020 Biennale Report on the Implementation of the African Growth and Opportunity Act, Page 89

The interesting fact in Table 5, which also ascertains the accrual of economic benefits for Sub-Saharan Africa following the evolvement of US trade and investment policy, is the high rate of US investment, 14\%, between 2009 and 2015. The search for US business opportunities in Sub-Saharan Africa led this country to negotiate multilateral and bilateral treaties seen as a means to implement its investment and trade objectives. US

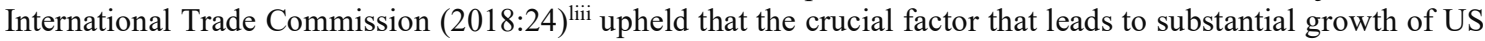
trade and investment in Sub-Saharan Africa countries is the set of the above platforms. The reason is that these platforms open up the path to more exports to the US from this region while rebalancing the costcompetitiveness of both partners' products (Ibid). Hence, the US kept multiplying initiatives to foster SubSaharan Africa development through trade and investment policy. In the same vein, a Member of the US-DRC Chamber of Commerce argued that successive US governments made an impressive contribution to trade capacity improvement and building for Sub-Saharan Africa countries essentially through Africa Growth and Opportunity Act, Africa Global Competitiveness Initiative, Multilateral Investment Frameworks, and the Millennium Challenge Corporation ${ }^{\text {liv }}$. Spector $(2010 \text {, p. 5) })^{\mathrm{lv}}$ argued that promoted duty-free access in the above way to American markets for exports from qualifying African nations demonstrated a growing interest in the use of US markets, trade and investment as key development components of Sub-Saharan Africa countries. Along the same line, Commerce Secretary Penny Pritzker commended the creation of the US-Africa Business Forum, 
which took place in 2014 and 2016 and brought together US and Sub-Saharan Africa investors and officials to facilitate US private sector engagement in the region, which generated $\$ 23.1$ billion in investment (US Department of Commerce, 2017) ${ }^{\mathrm{lvi}}$. Overall, these platforms boosted Sub-Saharan Africa countries exports and competitiveness, favoured access of their operations to the US financial system, improved business climate for US companies while advancing transparency over their natural resources and building infrastructure. According to Myovella et al. (2020) $)^{\text {lvii }}$, Sub-Saharan Africa governments should invest more in infrastructure to realize significant economic growth and development.

\section{Recent and current trend of US trade and Investments for Sub-Saharan Africa}

The unabated need to further Sub-Saharan Africa development through US trade and investment policy led the US government in President Trump's era to find a way of combining AGOA and MCC for their effectiveness. On this note, President Trump signed in April 2018, AGOA and Millennium Challenge Account Modernisation Act capable of facilitating transboundary trade among eligible Sub-Saharan African countries, offering appropriate training for business and government trade officials on accessing AGOA benefits, and providing capacity building for African trade associations and entrepreneurs on production strategies, market development and quality standards (US Congress, 2018) ${ }^{\text {lviii }}$. Hence, the above Act also kept rebalancing economic benefits in favour of Sub-Saharan Africa in a way that matched the desire of the US to provide a mechanism by which track economic development and progress could happen for this region. Brown $(2019 \text {, p. } 6)^{\text {lix }}$ explained that although considering that in its origin, MCC worked to reduce poverty through economic growth, it has focused on business practice that rested on fostering entrepreneurship, strengthening market forces, promoting engagement in regional and global trade, and respecting worker rights for the development of Sub-Saharan Africa countries. Kyeh Kim, Vice-president of MCC, echoed the above approach during the US-Africa Trade and Investment Forum when he explained that his organisation has engaged in concurrent compacts for regional investment and trade, which turn out to be a more valuable strategic tool for the US to promote development in Sub-Saharan Africa (Millennium Challenge Corporation, 2018) ${ }^{\mathrm{lx}}$. An Officer of the US Senate Committee on International Affairs confirmed the above view as he contended that this new approach also anticipates exploring cross-border investments in transport and power sectors deemed fundamental to boost regional integration and crucial to bringing Sub-Saharan African countries into the chain of global value for their development ${ }^{1 x i}$. Thus, the provisions above signposted the route to more economic benefits for Sub-Saharan Africa as never before, to the point that US trade and investment policy gave rise to more business segments within this region in pursuing its development. Owusu-Agyei and Hasan (2020) ${ }^{\mathrm{lxii}}$ explained that analysis reveals that sub-samples of Sub-Saharan Africa countries differ on their levels of economic development. Table 6 below exhibits fastest-growing US imports from SSA under AGOA between 2016 and 2018.

Table 11: Fastest-Growing US Imports from SSA under AGOA during 2016-2018

\begin{tabular}{|l|r|r|r|r|r|}
\hline \multicolumn{1}{|c|}{ Product } & $\begin{array}{c}\text { Year 2016 } \\
\text { Million US\$ }\end{array}$ & \multicolumn{1}{|c|}{$\begin{array}{c}\text { Year 2017 } \\
\text { Million } \\
\text { US\$ }\end{array}$} & $\begin{array}{c}\text { Year 2018 } \\
\text { Million US\$ }\end{array}$ & $\begin{array}{c}\text { Absolute } \\
\text { Change } \\
\mathbf{2 0 1 6 - 2 0 1 8}\end{array}$ & $\begin{array}{c}\text { Growth } \\
\text { Rate 2016- } \\
\mathbf{2 0 1 8}\end{array}$ \\
\hline Apparel & 1,010 & 1,033 & 1,218 & 209 & $9.9 \%$ \\
\hline Chemicals products & 109 & 113 & 204 & 95 & $36.8 \%$ \\
\hline Precious metals & 1,501 & 2,086 & 2,443 & 941 & $27.6 \%$ \\
\hline Crude petroleum & 5,912 & 8,879 & 12,100 & 1,657 & $13.8 \%$ \\
\hline Forest products & 20,160 & 24,857 & 25,075 & 4,915 & $11.5 \%$ \\
\hline Apparel & 1,010 & 1,033 & 1,218 & 209 & $9.9 \%$ \\
\hline
\end{tabular}

Source: US International Trade Commission, Publication Number 5043, Pages 75-102

Like in the previous period, what is revealing in Table 6 is the unremitting growth of US imports from SubSaharan Africa under AGOA and this trend applied to all products targeted by US trade and investment policy. As the momentum of the rebalancing of US-Sub-Saharan Africa economic benefits continued to build, the thenUS government launched Prosper Africa Initiative. Delivering a speech on this initiative in Washington, D.C. on 13 December 2018, US National Security Adviser John Bolton said, "Our first priority, enhancing US economic ties with the region, is not only essential to improving opportunities for American workers and businesses. It is also vital to safeguarding the economic independence and development of Sub-Saharan Africa" (White House, 
$2018)^{1 \mathrm{xiii}}$. Prosper Africa Initiative makes it easier than ever before for Africa investors and businesses to access an improved suite of a new whole-of-US government support package resource and services, including matchmaking, financing, insurance, and advisory services, to help advance new business opportunities for Africa development (US Department of State, 2020) ${ }^{\text {Ixiv }}$. Thus, accumulated to previous economic benefits for SubSaharan Africa development under AGOA and other business platforms, Prosper Africa Initiative connects US investors involved in economic opportunities thought to be suitable tools to chart the way forward for sustainable growth across this region. It then supports the economic recovery of this region to build back better a partnership. Saldinger $(2020)^{\mathrm{lxv}}$ argued that seen as an essential part of Trump's administration approach to driving the development of Sub-Saharan Africa substantially through business, Prosper Africa Initiative seeks to boost trade and investment that could uplift the countries in this part of Africa. From June 2019, the US Agency for International Development (2020) $)^{\text {lxvi }}$, which is the main implementing agency of Prosper Africa Initiative, has fostered a two-way trade and investment partnership with Sub-Saharan Africa. This implementation was based on the region development needs in closing more than 130 million in deals, $\$ 2.8$ billion in new exports and investments, and building a deal pipeline of more than $\$ 10$ billion (Ibid). A close look at the above figures suggests that this initiative aimed at doubling investment and trade between Sub-Saharan Africa and the US with the purpose of fostering the development of this region by offering more financial assets than before. This dynamism of US investment is evidenced by the trend of data in Table 7 below.

Table 12: US Investment in Sub-Sahara Africa (2016-2019) Billions of US dollars

\begin{tabular}{|c|c|c|c|c|}
\hline $\mathbf{2 0 1 6}$ & $\mathbf{2 0 1 7}$ & $\mathbf{2 0 1 8}$ & $\mathbf{2 0 1 9}$ & $\begin{array}{c}\text { Growth Rate } \\
(\mathbf{2 0 1 6 - 2 0 2 0})\end{array}$ \\
\hline 34.0 & 36.2 & 34.0 & 36.8 & $8.2 \%$ \\
\hline
\end{tabular}

Source: US Trade Representative, 2021 Report on the Implementation of the African Growth and Opportunity Act, Page 89

Table 7 exhibits a steady increase of US investments under the combined effect of Prosper Africa Initiative and AGAO, even though accompanied by a slight decline in 2018. Indeed, in parallel with Prosper Africa Initiative, the Trump administration kept implementing AGOA provisions to impulse the US-Sub-Saharan Africa trade relationship for the benefits of the last-named region. Thereupon, the US International Trade Commission $(2020)^{\text {lxvii }}$ unveiled that following this effort, leading AGOA import categories were Crude Oil (\$8.0 billion in 2018; down 13.6\% from 2017), Textiles and Apparel (\$1.2 billion; up 18.4\%), Minerals and Metals (\$728 million; down 12.3\%), Transportation Equipment (\$697 million; down 47.4\%), Agricultural Products (\$597 million, up 8.0\%), and Chemicals and Related Products (\$486 million, up 51.9\%). As also explained by an Economic Section Counsellor of US Embassy Brazzaville, through notably regional trade hubs located in Botswana, Ghana, Kenya and Senegal, AGOA allows Sub-Saharan Africa businesses and governments to benefit from US Government assistance, which helps their countries diversify their exports to the US ${ }^{\text {lxviii }}$. Therefore, AGOA was also at the epicentre of Trump's administration campaign and commitment intended to boosting Sub-Saharan Africa trade and investment to achieve the region's full potential at the pivotal moment in its trajectory for its development. Claussen $(2017 \text {, p. 384) })^{\text {lxix }}$ explained that under the Trump administration, USAfrican economic relationship was driven largely by the African Growth and Opportunity Act (AGOA), which creates trading privileges for Sub-Saharan Africa, reduces tariffs and creates opportunities for this region's products in the US market for its development. The narrative above ascertains that AGOA is a comprehensive platform, considering that in addition to providing legal guidance, it offers technical expertise and relevant information needed to expand the US-Sub-Saharan Africa trade partnership for the development of the lastnamed region.

President Joseph Biden administration also promotes Sub-Saharan Africa development through its exports under the African Growth and Opportunity Act and other mechanisms like President's Advisory Council on Doing Business in Africa. In its first term, President's Advisory Council on Doing Business in Africa strengthened commercial engagement between the US and Sub-Saharan Africa by producing several impactful reports (US Department of Commerce, 2021 $)^{\mathrm{lxx}}$. These reports informed US policies and programs to facilitate this region trade and investment, support job creation, promote best practices for doing business there, and help implement the Prosper Africa initiative (Ibid). Hence, President's Advisory Council on Doing Business in Africa also resulted in the accrual of economic benefits for Sub-Saharan Africa development. About AGOA under President

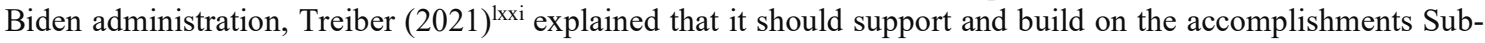
Saharan Africa has made in creating a more dynamic and integrated market that complies with the African Continental Free Trade Area (AfCFTA) agreement - while addressing the competitive disadvantages. The above illustrates, furthermore, an active US officials' engagement in the way that could significantly boost the ability 
of US-Sub-Saharan Africa trade partnership to serve as a suitable framework for sustainable development of the last-mentioned region. The US Office of Trade Representative (2021) $)^{\mathrm{lxxii}}$ disclosed that at the centre of AGOA are substantial trade preferences that, alongside those under the Generalized System of Preferences (GSP), enable virtually all marketable goods produced in AGOA-eligible countries to enter the US market duty-free. Similarly, a Journalist and Contributor to House Africa Subcommittee upheld that one of the merits of this Act is the setting of the annual US-Sub-Saharan Africa Economic Cooperation Forum, with the particular mission of promoting a high-level dialogue on investment and trade-related issues ${ }^{\text {lxxiii }}$. In a testimony before the Senate Subcommittee on Africa and Global Health Policy chaired by Christ Van Hollen, African Growth and Opportunity Act (GOA) was described as the cornerstone of the US trade policy towards Sub-Saharan Africa (US Senate, 2021) ${ }^{\text {lxxiv }}$. This is because apart from lowering tariffs, AGOA sets up innovative mechanism that resolves trade disputes and non-tariff barriers to trade, and adopts common regulations and standards (Ibid). It is clear that the above trend of US trade and investment policy seeks to transform US-Sub-Saharan Africa economic relationship from an aid-based perspective to a partnership centred on the development prescriptions of the countries belonging to this part of Africa.

The current US government also reinforced Prosper Africa Initiative through Proper Africa Trade and Investment (PATI) and Millennium Challenge Corporation (MCC) to reinvigorate Sub-Saharan Africa development by linking de-risk investment opportunities to finance solutions as well as backing business-facility policy reforms on the environment in this region. Indeed, President Biden announced on 27 July 2021 a new package of measures to expand trade ties between Sub-Saharan Africa and the US centred on clean energy, transport infrastructure and agribusiness in this region for its development by means of Prosper Africa and MCC platforms (White House, 2021). The above step also intended to incorporate development into the US-SubSaharan Africa trade and investment prescriptions and made the process of improving their partnership the anchor point of the dynamism of US trade and investment policy towards the region. Hruby $\left(2021\right.$, p. 5) ${ }^{1 \times x v}$ asserted that President Joe Biden administration targets a variety of economic sectors for catalytic support from US government agencies to mobilise additional investment and deepen development impact for Sub-Saharan Africa countries, including financial services, specialised oil and gas services, technology and media, and renewable energy. On this note, the Millennium Challenge Corporation signed a cooperative agreement with the West African Power Pool, which facilitates opportunities to increase US investment and trade in the energy sector, and in turn the development in this section of Africa (Millennium Challenge Corporation, 2021, p. 18) ${ }^{\text {lxxvi }}$. Hence, the current US government also attempts to accomplish the goal of Sub-Saharan Africa development by identifying and furthering new trade and investment opportunities. Therefore, US trade and investment are deemed capable of fuelling economic growth and jumpstarting jobs creation from key sectors in Sub-Saharan Africa countries.

The preceding demonstrates that this dynamism of US trade and investment aimed to cut America competitive advantages to unleash Sub-Saharan Africa countries development by setting an array of trade preference programmes pipelined by both partners' business opportunities. Dana Banks, Special Assistant to President Biden, explained at the virtual US-Africa Business Summit on 28 July 2021 that as part of the Prosper Africa Build Together Campaign, President Biden requested $\$ 80$ million to increase trade and investment in SubSaharan Africa by connecting US businesses with tangible deals and opportunities (US Department of State, 2021) ${ }^{1 x x v i i}$. Furthermore, the US Development Finance Corporation (DFC) committed nearly $\$ 2$ billion in financing for projects in Sub-Saharan Africa in the first half of the Fiscal Year 2021 and aims to close another $\$ 500$ million or more by the end of the fiscal year (Ibid). Thus, President Biden believes that Sub-Saharan Africa countries' fast-growing and dynamic economies mean their bright future-one featuring sustainable development and inclusive growth driven by trade and investment advantages granted by the US. A Professor of Global Business from John Hopkins University substantiated data on Millennium Challenge Corporation as he claimed that Biden Administration shifted its capacity building training to foster value-added processing and product diversification as well as technical and financial aid intended to help Sub-Saharan Africa businesses comply with US trade policies ${ }^{1 \mathrm{xx} x \mathrm{iii}}$. Likewise, Rattner and Whitmore $(2021, \text { p. 3) })^{\mathrm{lxxix}}$ explained that as competition results in trade disputes, rather than business projects that lock the potential of Sub-Saharan Africa, President Biden administration interest in trade with this economic partner is an opportunity for the US officials to advance policy goals centred on prosperity and balanced development of this region. This approach is necessary as it could boost the economic growth in Sub-Saharan Africa countries by strengthening their integration into the global market through the US, thereby accelerating their overall development. 


\section{Conclusion}

This article was concerned with the dynamism of US trade and investment towards Sub-Saharan Africa (SSA) to determine the rationale behind this trend. To that, the study prioritised empirical and qualitative approaches. It also relied upon the document review and interviews as data collection methods and on triangulation and content analysis as data analysis techniques. To achieve the mission of this paper alluded to above; systematic and methodical scrutiny of various US trade and investment instruments set up to re-balance US-Sub-Saharan Africa economic partnership in favour of the last-named regional entity was required. It turned out from data collected and analysed that the Africa Growth and Opportunity Act (AGOA), which is at the central stage of US-SubSaharan Africa trade and investment partnership, was designed and extended in a way that led to accrued economic benefits capable of fostering the development of Sub-Saharan Africa. This rationale also accounted for the inception of Millennium Challenge Corporation, Prosper Africa Initiative, African Global Competitiveness Initiative, US-Africa Business Forum, President's Advisory Council on Doing Business in Africa, and the signing of Trade and Investment Framework Agreements between the US and countries this region.

In practice, successive US governments worked with Sub-Saharan Africa countries through regional leaders and the private sector to improve the access of their products to the US. US officials also cut down barriers to this region's exports, relaxed customs tariffs, targeted prolific industries and in return, all the above initiatives could end up increasing the volume of Sub-Saharan Africa exports to the US. This is compounded by building institutional capacity on doing business, providing technical support on business climate and granting multifaceted flexibilities in connection with the above-mentioned schemes. This establishes to what extent the dynamism of US trade and investment policy towards Sub-Saharan Africa has systematically transformed into the accrual of economic benefits thought to be the engine of the development of this region. In this sense, practical and regulatory measures related to this dynamism provided an appealing alternative to Sub-Saharan Africa low development rhythm. Therefore, there is sufficient evidence pointing towards the fact that through the set of trade and investment instruments stage-managed by the US government, the development of Sub-Saharan Africa is the underlying reason for the dynamism of US trade and investment policy towards this region.

With its aim of scrutinising the development prescriptions of Sub-Saharan Africa through the dynamism of US trade and investment policy, this paper did not set out to assess whether or not this policy led inexorably to the development of this region. Thus, this study has just looked at how successive US governments have constantly rewrite the rules of their trade and investment policy in a way that could foster the development of Sub-Saharan Africa. This finding suggests that rather than one-sided trade and investment policy or a more balanced partnership, US officials are prone to grant accumulating economic advantages to Sub-Saharan Africa countries for their development. Beyond this main finding of this study as referred to above, it is worth saying that the significance of this continent as a US partner is ever underscored as compared to other world regions. In closing, various approaches used to collect and analyse data ensured that the produced account of the US trade and investment policy towards Sub-Saharan Africa from the development perspective of this region is rich and comprehensive. That is because this approach helped proceed with this study for the satisfactory analysis to the extent that it turned out to be a key to substantiating the contribution that this study is making in its field of research. Considering that measuring the impact of US trade and investment on SSA development in not within the remit of this study while this approach is also relevant, it could therefore form another investigation track for future research.

\section{Annex I: Chronology of US Business Platforms for SSA Development}

\begin{tabular}{|c|c|c|}
\hline Name of Business Platforms and Benefits for Sub-Saharan Africa (SSA) & Date & $\begin{array}{c}\text { Presiden } \\
\mathrm{t}\end{array}$ \\
\hline $\begin{array}{c}\text { Trade and Tariff Act of } 1998 \\
* \quad \text { Reduced tariffs and non-tariff barriers for SSA products } \\
* \quad \text { Cut obstacles to some articles from SSA } \\
* \quad \text { Permitted US aid to the SSA integration }\end{array}$ & $\begin{array}{c}31 \\
\text { July } \\
1998\end{array}$ & $\begin{array}{c}\text { Bill } \\
\text { Clinton }\end{array}$ \\
\hline $\begin{array}{l}\text { Africa Growth and opportunity Act (AGOA) of } 2000 \\
\quad \text { Allowed access of SSA products restricted by the World Trade Organisation }\end{array}$ & $\begin{array}{l}18 \\
\text { May }\end{array}$ & $\begin{array}{l}\text { Bill } \\
\text { Clinton }\end{array}$ \\
\hline
\end{tabular}




\begin{tabular}{|c|c|c|}
\hline $\begin{array}{l}\text { Eliminated duties on exports from all eligible SSA countries } \\
\text { - Implemented quota-free for some SSA products }\end{array}$ & 2000 & \\
\hline $\begin{array}{l}\text { US-Common Market for Eastern and Southern Africa TIFA } \\
* \text { Recognised the essential role of US private investments in this SSA region } \\
* \text { Reduced non-tariff barriers to further exports of this SSA region to the US } \\
* \quad \text { Recognised the significance of SSA development through this region }\end{array}$ & $\begin{array}{l}29 \\
\text { October } \\
2001\end{array}$ & $\begin{array}{l}\text { George } \\
\text { W. } \\
\text { Bush }\end{array}$ \\
\hline $\begin{array}{l}\text { Millennium Challenge Corporation } \\
\text { * Made substantial new financial resources available } \\
\text { * Opened US market for SSA businesses facing gauntlets of bureaucracy } \\
\text { * Empowered SSA companies to promote economic growth and fight poverty }\end{array}$ & $\begin{array}{c}\text { January } \\
2004\end{array}$ & $\begin{array}{l}\text { George } \\
\text { W. } \\
\text { Bush }\end{array}$ \\
\hline $\begin{array}{l}\text { African Global Competitiveness Initiative } \\
* \text { Advocated the diversification of African countries exports } \\
* \text { Helped these countries match their products with US requirements } \\
* \quad \text { Improved these countries' capacity to meet international quality standards }\end{array}$ & $\begin{array}{c}07 \\
\text { June } \\
2005\end{array}$ & $\begin{array}{l}\text { George } \\
\text { W. } \\
\text { Bush }\end{array}$ \\
\hline $\begin{array}{c}\text { US-Easter African Community Trade and Investment Framework Agreement } \\
\text { * Tied US-Eastern African countries through cooperation for development } \\
\text { * Helped strengthen their economy and expand trade for their development } \\
* \quad \text { Reduced more non-tariff barriers to facilitate access to the US market }\end{array}$ & $\begin{array}{l}16 \\
\text { July } \\
2008\end{array}$ & $\begin{array}{l}\text { George } \\
\text { W. } \\
\text { Bush }\end{array}$ \\
\hline $\begin{array}{l}\text { US-Economic Community of West African Countries TIFA } \\
* \quad \text { Identified specific trade and investment areas to be funded by the US } \\
* \text { Removed impediments from the US side for this SSA region }\end{array}$ & $\begin{array}{l}04 \\
\text { August } \\
2014\end{array}$ & $\begin{array}{l}\text { Barack } \\
\text { Obama }\end{array}$ \\
\hline $\begin{array}{l}\text { President's Advisory Council on Doing Business in Africa } \\
\text { * Strengthened commercial engagement between the US and Africa } \\
* \quad \text { Provided the US with information to facilitate SSA trade and investment in US }\end{array}$ & $\begin{array}{l}05 \\
\text { August } \\
2014\end{array}$ & $\begin{array}{l}\text { Barack } \\
\text { Obama }\end{array}$ \\
\hline $\begin{array}{c}\text { Extension of AGOA through Trade Preferences Extension Act of } 2015 \\
\text { Designated cotton articles as eligible for preferential treatment only for SSA } \\
* \text { Set a number of travel articles for duty-free treatment } \\
* \quad \text { Eliminated restrictions on SSA investments in the US }\end{array}$ & $\begin{array}{c}29 \\
\text { June } \\
2015\end{array}$ & $\begin{array}{l}\text { Barack } \\
\text { Obama }\end{array}$ \\
\hline $\begin{array}{l}\text { US-Africa Business Forum } \\
* \quad \text { Brought together US and SSA investors and officials for efficient cooperation } \\
* \quad \text { Facilitated US private sector engagement in SSA }\end{array}$ & $\begin{array}{l}07 \\
\text { January } \\
2017\end{array}$ & $\begin{array}{l}\text { Barack } \\
\text { Obama }\end{array}$ \\
\hline $\begin{array}{c}\text { AGOA and Millennium Challenge Account Modernization Act of } 2018 \\
* \quad \text { Facilitated transboundary trade among eligible SSA countries } \\
* \quad \text { Offered training to trade officials on accessing AGOA benefits } \\
* \quad \text { Provided capacity building for SSA on production strategies and value-added }\end{array}$ & $\begin{array}{l}23 \\
\text { April } \\
2018\end{array}$ & $\begin{array}{l}\text { Donald } \\
\text { Trump }\end{array}$ \\
\hline $\begin{array}{l}\text { Prosper Africa Initiative } \\
* \quad \text { Enhanced US economic ties with SSA } \\
* \quad \text { Improved opportunities for American workers and businesses in SSA }\end{array}$ & $\begin{array}{l}17 \\
\text { Novemb } \\
\text { er } \\
2020\end{array}$ & $\begin{array}{l}\text { Donald } \\
\text { Trump }\end{array}$ \\
\hline
\end{tabular}


Journal of Economics and Sustainable Development

ISSN 2222-1700 (Paper) ISSN 2222-2855 (Online)

\begin{tabular}{|c|c|}
\hline Safeguarded the economic independence and development of SSA & \\
\hline $\begin{array}{c}\text { Prosper Africa Trade and Investment } \\
* \quad \text { Helped link de-risk investment opportunities to finance solutions in SSA }\end{array}$ & $\begin{array}{c}\text { February } \\
2021\end{array}$ \\
$\begin{array}{c}\text { Backed business-facility policy reforms on the environment in SSA } \\
\text { Biden }\end{array}$ \\
\hline
\end{tabular}

Annex II: Open-Ended Questions

Name of Organisation: XXX

Identification code of respondent: XXX

Under the current circumstances of US-Africa trade relationship, the internal needs for US firms, the requirements of global trade and the needs for the development of Sub-Saharan Africa; what are the stakes involved in US trade and investment policy towards this region?

Answer to question no. 1

Question no. 2

In line with business initiatives set up by US to deal with its trade and investment policy towards Sub-Saharan Africa; what is according to you, the reason behind this dynamism?

Answer to question no. 2

Question no. 3

Many believe that the US seeks to promote its economic interests through trade and investment policy; does this rationale apply to the US-Sub-Saharan Africa partnership?

Answer to question no. 3

Annexe II: List of Respondents

\begin{tabular}{|c|c|c|c|c|}
\hline Code & Name & Title and Organisation & Date & Venue \\
\hline 01 & Confidential & $\begin{array}{l}\text { Former Country Director of US Agency for } \\
\text { International Development }\end{array}$ & $18 / 12 / 20$ & N/A (Skype) \\
\hline 02 & Confidential & $\begin{array}{l}\text { Executive Director of US Office for } \\
\text { International trade }\end{array}$ & $21 / 12 / 20$ & N/A (Email) \\
\hline 03 & Confidential & Director of US Bureau of Trade Representative & $28 / 12 / 20$ & $\begin{array}{l}\text { N/A MS } \\
\text { Teams }\end{array}$ \\
\hline 04 & Confidential & $\begin{array}{l}\text { Director of US Government Accountability } \\
\text { Office }\end{array}$ & $08 / 04 / 21$ & N/A Zoom \\
\hline 05 & Confidential & US Congressional Research Service Officer & $13 / 04 / 21$ & N/A (Email) \\
\hline 06 & Confidential & Member of US-DRC Chamber of Commerce & $28 / 04 / 21$ & N/A Zoom \\
\hline 07 & Confidential & $\begin{array}{l}\text { Officer of US Senate Committee on } \\
\text { International Affairs }\end{array}$ & $14 / 05 / 21$ & $\begin{array}{l}\text { N/A MS } \\
\text { Teams }\end{array}$ \\
\hline 08 & Confidential & $\begin{array}{l}\text { Economic Section Counsellor/US Embassy } \\
\text { Brazzaville }\end{array}$ & $05 / 06 / 21$ & N/A (Zoom) \\
\hline 09 & Confidential & $\begin{array}{l}\text { Journalist/Contributor to House Africa } \\
\text { Subcommittee }\end{array}$ & $14 / 06 / 21$ & N/A Zoom \\
\hline 10 & Confidential & $\begin{array}{l}\text { Professor of Global Business/John Hopkins } \\
\text { University }\end{array}$ & $19 / 06 / 21$ & N/A (Email) \\
\hline
\end{tabular}


eference

${ }^{\mathrm{i}}$ Irwin, D. (2017) Clashing over Commerce: A History of US Trade Policy. Chicago: University of Chicago Press

ii US Trade Administration (2020). Report on the Implementation of the African Growth and Opportunity Act. Washington, D.C: USTA

iii Card, H. et al. (2011) US Trade and Investment Policy. Washington, D.C: Council on Foreign Relations

iv Copley, A. (2018) US President's Advisory Council on Doing Business in Africa Visits Ethiopia, Kenya, Côte d'Ivoire and Ghana. Africa Growth Initiative. https://www.brookings.edu/blog/africa-in-focus/2018/07/06/africa-in-the-news-us-africabusiness-council-au-summit-and-nigeria-updates

v US Department of Commerce (2017) US Department of Commerce Strategic Plan 2018-2022. Washington, D.C: USG Printing Office.

${ }^{v i}$ Lasswell, H. (2002) The Analysis of Political Behaviours: An Empirical Approach. New York: Routledge

vii Creswell, J. (2009) Research Design: Qualitative, Quantitative and Mixed Methods Approaches. London: Sage Publications

viii Scott, J. (2006) Documentary Research. Thousand Oaks: SAGE Publications

${ }^{i x}$ Alvesson, M. (2002) Postmodernism and Social Research. Philadelphia: OU Press

${ }^{x}$ Roberts, E. et al. (2014) 'Structural Topic Models for Open-Ended Survey Responses'. American Journal of Political Science 58(4), 1064-1082

${ }^{x i}$ Oppenheim, A. (2001) Questionnaire Design, Interviewing and Attitude Measurement. London: Continuum International Publishing.

xii Yeasmin, S. and Rahman, K. (2012) 'Triangulation Research Method as the Tool of Social Science Research'. Bristol University Press Journal 1(1), 154-163

xiii Pelto, P. (2017). Mixed Methods in Ethnographic Research: Historical Perspectives. London: Routledge.

${ }^{\text {xiv }}$ Hsieh, H. and Shannon, S. (2005). Three Approaches to Qualitative Content Analysis, Sage Journal of Qualitative Research, 15(9), pp. 1277-1288. https://doi.org/10.1177/1049 732305276687.

${ }^{x v}$ Yang et al. (2011). The development of a content analysis model for assessing students' cognitive learning in asynchronous online discussions. Education Technology Research Development, 59(1). pp. 43-70. DOI: 10.1007/s11423-010-9166-1

xvi White House (2002) Selected Speeches, Al Gore, Vice President of the United States. https://clintonwhitehouse2.archives.gov/WH/EOP/OVP/speeches_bottom.html

xvii US Department of State (1996) 'Remarks of George Moose, Assistant Secretary of State for African Affairs on Trade and Investment in Sub-Saharan' San Francisco, 14 April 1996. http://dosfan.lib.uic.edu/ERC/bureaus/afr/950404AfricaTrade.html.

xviii Dagne, T. (1998) Africa: Trade and Development Initiatives by the Clinton Administration and Congress. US Congressional Research Service. https://www.everycrsreport. com/files/19980302_98-92_1a4b9a9303a5fbd67a6574fbf73ad72bb01266dd.pdf.

xix US Congress (1998) 'Trade and Tariff Act of 1998', 31st July 1998, 105th Congress, 2nd Session. https://www.congress.gov/congressional-report/105th-congress/senate-report/280.

${ }^{x x}$ Skype interview on 12 December 2020

xxi US House of Representatives (1998) Trade and Tariff Act of 1998. https://search.house. gov/?search $=+$ trade + and + Tariff + Act + of +1998

xxii Email exchange with an Executive Director of the US Office for International Trade on 21

December 2020

xxiii US Trade Representative (2009) Toward a New U.S.-African Partnership on Trade and Development. $\quad$ https://ustr.gov/about-us/policy-offices/press-office/blog/toward-new-usafrican-partnership-trade-and-development 
${ }^{x x i v}$ Thompson, C. (2004) US Trade with Africa: African Growth and Opportunity. Review of African Political Economy, 31(101), pp. 457-474. https://www.jstor.org/stable/4006 967.

${ }^{x x v}$ White House (2000) Public Papers of the Presidents of the United States: William Clinton, Washington: GPO

${ }^{x x v i}$ Schraeder, J. (1998) Trends and Transformation in the Clinton Administration's Foreign Policy toward Africa (1993-1999), Journal of Opinion, 26(2), pp 1-7. https://www.jstor.org/stable/1166820

xxvii Clinton Presidential Library and Museum (2000) From Containment to Enlargement: Statement of the National Security Affairs. https://clinton.Presidentiallibraries.us/ solrsearch? $=$ From + Containment+to+Enlargement $\%$ E2\% 80\%99.

xxviii US Congress (1999) African Growth and Opportunity Act, 106th Congress, 1st Session, 13th July 1999. https://www.congress.gov/congressional-report/106th-congress/house -report/19/1.

xxix Zappile, T. (2011) Nonreciprocal Trade Agreements and Trade: Does the African Growth and Opportunity Act (AGOA) Increase Trade? International Studies Perspectives. 12(1), pp. 4667. https://doi.org/10.1111/j.1528-3585.2010.00419.x

${ }^{x x x}$ US Trade Representative (2010) US-Common Market for Eastern and Southern Africa (COMESA) Trade \& Investment Framework Agreements. https://ustr.gov/sites/ default/files/uploads/agreements/tifa/asset_upload_file367_7725.pdf

xxxi MS Teams interview on 28 December 2020

xxxii White House (2004) The Millennium Challenge Account. https://georgewbush-whitehouse .archives.gov/infocus/developingnations/millennium.html

xxxiii US Department of State (2005) African Global Competitiveness Initiative. https://20012009 .state.gov/p/af/rls/fs/49817.htm.

xxxiv US Trade Representative (2012) US-Easter African Community Trade and Investment Framework Agreement. asset_upload_file413_15020.pdf

${ }^{\mathrm{xxxv}}$ Yannaca-Small, $\overline{\mathrm{K}}$. (2010) Arbitration under International Investment Agreements: A Guide to the Key Issues. New York: Oxford University Press

xxxvi White House (2007) Trade Adjustment: Expanding Opportunity. https://georgewbushwhitehouse.archives.gov/infocus/internationaltrade/taapager.html

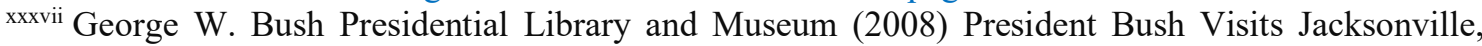
Florida, Discusses Trade Policy. http://www.georgewbushlibrary.smu.edu/Research /DigitalLibrary//https://georgewbush-whitehouse.archives.gov/ news/releases/2008/03/20080318-4.html.

xxxviii Zoom Interview on 04 April 2021

xxxix Vandevelde, K. (2009) US International Investment Agreements. Oxford: Oxford University Press

${ }^{x 1}$ US Department of the Treasury (2007) Evidence of Progress-Growth and Investment, Remarks by Secretary Henry Paulson, before the US-Africa Business Summit on Change and Progress in Africa's Economic Development. https://www.treasury.gov/ press-center/pressreleases/Pages/hp687.aspx.

xli US Representative to the World Trade Organization (2010) Statement of the US as Delivered by $\mathrm{Mr}$ David Shark Deputy Permanent Representative to the WTO, 24 $4^{\text {th }}$ November 2010. https://geneva.usmission.gov/2010/11/24/tpr-drcongo.

xlii White House (2015) On Trade: What the President Signed into Law. https:/obama whitehouse.archives.gov/blog/2015/06/29/trade-here-s-what-president-signed-law.

xliii US Congress (2015) Trade Preferences Extension Act of 2015. https://www.congress.gov/ 114/plaws/pub127/PLAW-114pub127.pdf.

xliv Jones, M. (2017) Improving Free Trade between Sub-Saharan Africa and the US: The Current Agreement, Potential Solutions and Public Diplomacy Strategies. Los Angeles: USC

${ }^{\text {xlv }}$ Email exchange on 04 April 2021 
xlvi White House (2014) Executive Order --Establishing the President's Advisory Council on Doing Business in Africa. https://obamawhitehouse.archives.gov/the-press-office/ 2014/08/05/executive-order-establishing-presidents-advisory-council-doing-business.

xlvii The American Presidency Project (2017) Barack H. Obama: 44th President of the United States, 2009-2017. Washington, D.C.: US Government Printing Office

xlviii Ashbee, E, and Dumbrell, J. (2017) The Obama Presidency and the Politics of Change. London: Palgrave Macmillan

xlix Barack Obama Presidential Library (2017) Remarks by the President at Cairo University, 6-04-09. https://search.obamalibrary.gov/search?query=remarks+by+the+president+at + cairo + university\&utf $8=\&$ affiliate $=$ bamalibrary\&submit $=$ remarks by the President at Cairo University, 6-04-09.

${ }^{1}$ Hendrickson, R. (2014) Promoting U.S. Investment in Sub-Saharan Africa. London: Palgrave MacMillan

${ }^{\text {li }}$ US Trade Representative (2014) US-Economic Community of West African Countries Trade and Investment Framework Agreement. https:/ustr.gov/sites/default/files/files/ agreements/tifa/U.S.\%20Economic $\% 20$ Community $\% 20$ of $\% 20$ West $\% 20$ African $\% 20$ States $\% 2$ 0ECOWAS\%20TIFA.pdf.

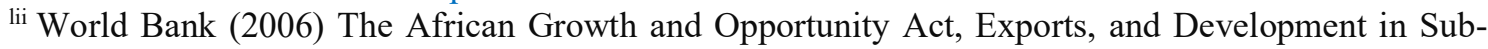
Saharan Africa. Washington: WB

liii US International Trade Commission (2018) US Trade and Investment with Sub-Saharan Africa: Recent Developments. Washington: USITC

liv Zoom interview on 28 April 2021

${ }^{1 v}$ Spector, B. (2010) The United States and Africa in the Obama Era: New wine in old bottles, old bottles for a new beverage - Or a new label on an old brew? Johannesburg: CPS

lvi US Department of Commerce (2017) Cabinet Exit Memo by Secretary Penny Pritzker. https://www.commerce.gov/news/fact-sheets/2017/01/cabinet-exit-memo-secretary-pennypritzker

${ }^{\text {lvii }}$ Myovella, G. et al. (2020) Digitalization and economic growth: A comparative analysis of SubSaharan Africa and OECD economies, Telecommunications Policy. 44(2) .https://doi.org/10.1016/j.telpol.2019.101856

lviii US Congress (2018) Africa Growth and Opportunity and Millennium Challenge Accounts Modernization Act. $115^{\text {th }}$ Congress. https://www.congress.gov/115/plaws /publ167/PLAW-115publ167.pdf

lix Brown, N. (2019) Millennium Challenge Corporation: Overview and Issues. Congressional Research Service. https://fas.org/sgp/crs/row/RL32427.pdf

${ }^{1 x}$ Millennium Challenge Corporation (2019) MCC Highlights New Regional Investment Authority at Africa Business Forum. https://www.mcc.gov/news-and-events/release/ release-021219regional-africa-business-forum.

Ixi MS Teams Interview on 14 May 2021

lxii Owusu-Agyei, S. and Husan, F. (2020) Internet adoption and financial development in sub-Saharan Africa. Technological Forecasting and Social Change. https://doi.org/10.1016/ j.techfore.2020.120293.

lxiii White House (2018) Remarks by National Security Advisor Ambassador John R. Bolton on the Trump Administration's New Africa Strategy. https://trumpwhitehouse.archives. gov/briefings-statements/remarks-national-security-advisor-ambassador-john-r-bolton -trumpadministrations-new-africa-strategy/.

lxiv US Department of State (2020) The Prosper Africa Initiative Drives U.S. Investment in Africa. https://2017-2021.state.gov/the-prosper-africa-initiative-drives-u-s-investment -inafrica/index.html

${ }^{1 x v}$ Saldinger, A. (2020) Taking stock of the Trump administration's Africa policy. Inside Development. https://www.devex.com/news/taking-stock-of-the-trump-administration -s-africa-policy97386. 
Ixvi US Agency for International Development (2020) Prosper Africa. https://www.usaid .gov/prosperafrica\#: : text=The $\% 20$ Prosper $\% 20$ Africa $\% 20$ initiative $\% 20$ brings,growth $\% 2 \mathrm{C} \% 2$ 0and $\% 20$ fosters $\% 20$ shared $\% 20$ prosperity.

Ixvii US International Trade Commission (2020) U.S. Trade and Investment with Sub-Saharan Africa: Recent Trends and New Developments. https://agoa.info/images/documents /15766/pub5043usitc-report.pdf

lxviii Zoom Interview on 05 June 2021

${ }^{1 x i x}$ Claussen, K. (2017) The Next Generation of US-Africa trade Instruments. American Journal of International Law, 111(2017), pp. 384 - 388. doi:10.1017/aju.2017.79

${ }^{1 x x}$ US Department of Commerce (2021) Meeting of the President's Advisory Council on Doing Business in Africa. https://www.commerce.gov/videos/meeting-presidents-advisory-councildoing-business-africa

Ixxi Treiber, L. (2021) It's Time for a New Economic Partnership with Africa. Centre for Strategic and International Studies. Washington, DC: CSIS. https://www.csis.org/analysis/its-time-neweconomic-partnership-africa

1xxii US Office of Trade Representative (2021) African Growth and Opportunity Act (AGOA) https:/ustr.gov/issue-areas/trade-development/preference-programs/african-growth-andopportunity-act-agoa

1xxiii Zoom Interview on 14 June 2021

lxxiv US Senate (2021) US Trade and Investment in Africa. Testimony before the Senate Subcommittee on Africa and Global Health. https://www.foreign.senate.gov/imo/ media/doc/072821_Liser_Testimony.pdf

${ }^{1 x x v}$ Hruby, A. (2021) Priorities for US-Africa Commercial Policy in the Biden Administration. Washington, D.C.: Atlantic Council

1xxvi US Millennium Challenge Corporation (2021) Economic Growth through Innovation, Reform, and Accountability. https://www.mcc.gov/resources/pub-pdf/annual-report-2020

lxxvii US Department of State (2021) Digital Press Briefing on U.S.-Africa Trade and Investment through Prosper Africa. https://www.state.gov/digital-press-briefing-on-u-s-africa-trade-andinvestment-through-prosper-africa/

lxxviii Email exchange on 06 June 2021

${ }^{1 x x i x}$ Rattner, R. and Whitmore, B. (2021) President Biden's Africa policy. London School of Economic Strategic Update. https://www.lse.ac.uk/ideas/Assets/Documents/updates /LSE-IDEASPresident-Bidens-Africa-Policy.pdf 